\section{Fate of hexavalent chromium in a multicomponent system}

FATAI OLABANJI BALOGUN ${ }^{1}$, MIRANDA AIKEN ${ }^{2}$, ALIREZA NAMAYANDEH ${ }^{3}$, OWEN DUCKWORTH ${ }^{4}$ AND MATTHEW POLIZZOTTO ${ }^{5}$

${ }^{1}$ University of Oregon

${ }^{2}$ University of California Riverside

${ }^{3}$ Virginia Tech

${ }^{4}$ North Carolina State University

${ }^{5}$ University Of Oregon

Presenting Author: fbalogun@uoregon.edu

Toxic chromium (Cr) contamination of soils and water from anthropogenic and geogenic sources is a pervasive environmental and health issue. The toxicity of $\mathrm{Cr}$ is highly dependent on its interactions in the environment. Manganese (Mn) oxides are very ubiquitous, and prolific in facilitating $\mathrm{Cr}$ (III) oxidation [1]. Also, in environmental systems, $\mathrm{Cr}$ availability and reactivity is dependent on the suite of structurally diverse natural dissolved organic carbon (DOC). These confounding factors make it difficult to assess the specific risks of $\mathrm{Cr}$ contamination in natural systems.

The objective of this study is to evaluate the mechanisms of $\mathrm{Cr}$ redox dynamics as function of Mn-induced oxidation, DOC concentration and DOC functional group composition. To address these objectives, mixed batch experiments using synthesized $\mathrm{Cr}$ hydroxide, manganese oxide $(50 \mathrm{~nm})$, citric and gallic acid as DOC source was conducted for a period of 2 weeks. Dissolved $\mathrm{Cr}(\mathrm{VI})$, total $\mathrm{Cr}[\mathrm{Cr}]_{\mathrm{T}}$ and $\mathrm{Mn}[\mathrm{Mn}]_{\mathrm{T}}$ has been be quantified in order to elucidate mechanisms of $\mathrm{Cr}(\mathrm{VI})$ production across DOC gradients of $0.5-10 \mathrm{mM}$.

Preliminary results at $\mathrm{pH} 5$ show that $\mathrm{Cr}(\mathrm{VI})$ production is a function of citric acid concentration. At a starting of concentrations $0.5 \mathrm{mM}$, citric acid caused rapid $\mathrm{Cr}(\mathrm{VI})$ production which peaked at $5.2 \mu \mathrm{m}$ within 48 hours. However, within the same period, $10 \mathrm{mM}$ citric acid produced 7.5 times less $\mathrm{Cr}(\mathrm{VI})$ (Fig A). This is lesser than the $1.92 \mu \mathrm{m}$ threshold for total $\mathrm{Cr}$ set by the USEPA for drinking water [2]. Conversely, increasing concentration of citric and gallic acid increased $[\mathrm{Cr}]_{\mathrm{T}}$ concentration (Fig B and C).

Ongoing work seeks to quantify $\mathrm{Cr}(\mathrm{VI})$ concentration with gallic acid as DOC and measure changes in gallic acid and citrate concentrations in concert with $\mathrm{Cr}$ redox processes. X-ray absorption spectroscopy data are being analyzed to determine solid phase speciation of $\mathrm{Cr}$ and $\mathrm{Mn}$. These results will show the efficacy of DOC in limiting $\mathrm{Cr}$ oxidation and help better understand fate of $\mathrm{Cr}$ in multi-component systems.

\section{References}

[1] Oze et al. (2007). Proceedings of the National Academy of Sciences, 104(16), 6544-6549.

[2] Pan et al. (2019). ACS Earth and Space Chemistry, 3(3), $357-365$

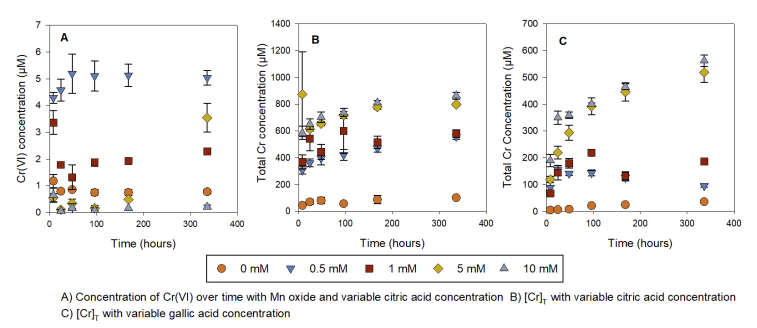

